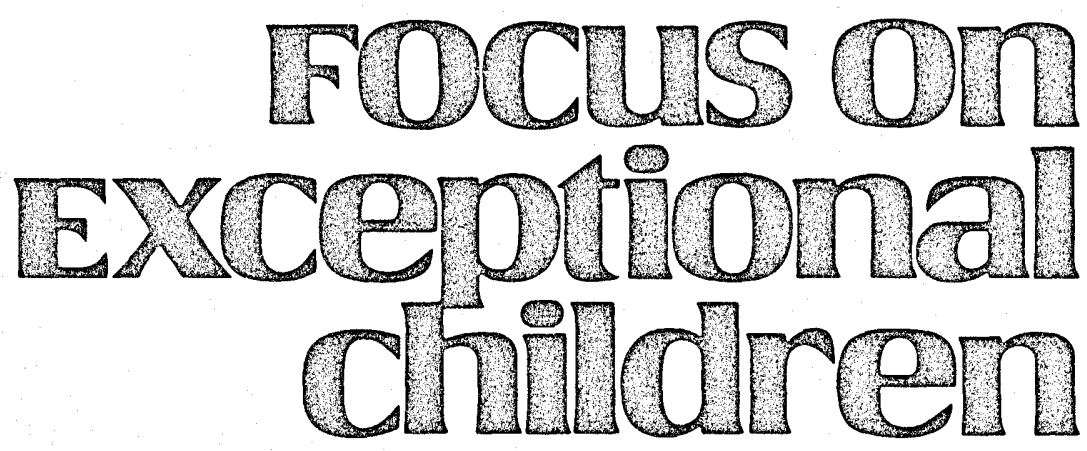

\title{
Rethinking the Relationship Between Consultation And Collaborative Problem-Solving
}

Marleen C. Pugach and Lawrence J. Johnson

Professionals in the field of special education have responded to the challenge of how best to meet the needs of students with mild learning and behavior problems by introducing a variety of informal service delivery options that have come to be known as prereferral interventions. These procedures are designed to provide intervention assistance quickly and informally to general educators. The intent is to enhance communication between special and general education teachers and to prevent the need for lengthy and costly student evaluations and placement in special education by remediating student difficulties in a timely, efficient manner within the general education environment. As a result, general educators should become more independent in their abilities to solve problems and be less likely to access the special education system unnecessarily.

Prereferral interventions grew out of an increasing recognition of the restrictive nature of procedures by which students become eligible to receive special education services. They represent an attempt to place a greater proportion of special education's resources into more informal, immediate service delivery approaches and a lesser proportion into diagnosis, prescription, and formal staffing procedures and meetings.

Among the major forms of prereferral service delivery is consultation on the part of special education teachers (Fox et al., 1973; Fuchs \& Fuchs, in press; Idol, Paolucci-Whitcomb, \& Nevin, 1986). The purpose of special education consultation is to have special education teachers work directly with general educators to develop specific instructional and management interventions for students with learning and behavior problems. With programs of consultation in place, general educators receive immediate help in problem identification, intervention, and monitoring of student behavior. Consultation services such as these are not delivered by special education teachers alone; school psychologists also have promoted their use (Graden, Casey, \& Christenson, 1985; Shapiro, 1987) and have been successful in implementing similar consultation services at the school level (Ponti, Zins, \& Graden, 1988).

Marleen Pugach is Assistant Professor, Department of Curriculum and Instruction, University of Wisconsin-Milwaukee. Lawrence Johnson is Associate Professor, Area of Special Education, University of Alabama.

(C) Love Públishing Company, 1988.

\section{Teacher Management and Helping Style: How Can We Develop Student Self-Control?}

Charles A. Chrystal (see p. 9) 
As it is most commonly practiced, consultation is a one-toone relationship based on the belief that as general educators are able to utilize data-based approaches through consultation with a specialist, their students will enjoy greater success in school. Although the specifics of consultation services may differ from program to program, typically they are based on a triadic model of interaction between the student as the target of concern, the general educator as mediator of the change, and the specialist as the consultant (Tharp \& Wetzel, 1969). General educators, under the guidance of specialists, are encouraged to use data-based techniques to identify problem behaviors and monitor progress once interventions are started. Interventions are developed jointly and implemented for the target student or students by general educators. As a consequence, general educators are afforded the input of a specialist who helps the teacher use more systematic approaches with students who have difficulty finding success in school.

\section{Focus on Exceptional children}

FOCUS ON EXCEPTIONAL CHILDREN (ISSN0015-511X) (USPS 203-360) is published monthly except June, July, and August as a service to teachers, special educators, curriculum specialists, administrators, and those concerned with the special education of exceptional children. This publication is annotated and indexed by the ERIC Clearinghouse on Handicapped and Gifted Children for publication in the monthly Current Index to Journals in Education (CIJE) and the quarterly index, Exceptional Child Education Resources (ECER). It is also available in microform from Xerox University Microfilm, Ann Arbor, MI. Subscription rates: Individuals, $\$ 24$ per year; institutions, $\$ 30$ per year. Copyright (C) 1988, Love Publishing Company. All rights reserved. Reproduction in whole or part without written permission is prohibited. Printed in the United States of America. Second class postage is paid at Denver, Colorado.

POSTMASTER: Send address changes to:

Love Publishing Company

Executive and Editorial Office

1777 South Bellaire Street

Denver, Colorado 80222

Telephone (303) 757-2579

EDITORIAL BOARD

$\begin{gathered}\text { Edward L. Meyen } \\ \text { University of Kansas } \\ \text { Richard J. Whelan } \\ \text { Georgia State University }\end{gathered}$
University of Kansas Medical Center
$\begin{gathered}\text { Stanley F. Love } \\ \text { Publisher }\end{gathered}$
Carolyn Acheson
Senior Editor

Consultation between adult professionals in the schools is an extremely important value for educators to promote. Through joint problem-solving, teachers are able to focus expertise on particular problems of teaching practice; collegial interaction encourages pairs of teachers and consultants to develop strong working relationships from which both can benefit by receiving mutual reinforcement. Further, with the introduction of consultation, special educators engage in greater interaction with general education around problematic situations, modeling among adults at a different but no less important level what integration is meant to do for handicapped and nonhandicapped students. Also, by supporting the development of consultation, special education professionals express their awareness that change is needed in the way special education services now are obtained. Equally important, consultation as a value appears to be consistent with educational reform efforts that stress increased responsibility for decision-making on the part of teaching professionals.

In principle, then, consultation is a collaborative endeavor, one that is meant to share expertise in developing new teaching skills on the part of general educators, who in turn can become more self-sufficient and less dependent upon support from special education. As often occurs when a new model is implemented, however, the practice of consultation may not be consistent with the intent of its underlying principles. At this point in its development, consultation is not yet well accepted despite its apparent value; in comparison to other activities, special educators actually spend little time consulting (see Evans, 1980; Idol-Maestas \& Ritter, 1985; Sargeant, 1981).

\section{PROBLEMS IN THE PRACTICE OF CONSULTATION}

Elsewhere we have argued that existing conceptual and pragmatic barriers seriously inhibit the potential of consultation as a collaborative mode of professional interaction (Johnson, Pugach, \& Hammitte, in press). Germane to this discussion are five practices, described in detail later in this article, stemming from the common presupposition that the expertise belonging to those trained in special education or school psychology puts these particular professionals in the position of being most well suited to take on the consulting role. As a result of this hierarchical orientation on the part of support services specialists who practice consultation, the joint and collaborative intent of consultation is diminished. Instead, a top-down approach exists, in which general educators typically are characterized as needing assistance and specialists as typically being sources of assistance. 
Recognizing the potential problem inherent in this kind of relationship, Idol et al. (1986) have attempted to break away from an expert model of consultation, proposing instead a variation of the triadic model of consultation called collaborative consultation. This form of consultation is described as a reciprocal arrangement between individuals with diverse expertise to define problems and develop solutions mutually.

As defined in the collaborative consultation model, general educators, special educators, speech therapists, principals, parents, or others might serve in the role of consultant. In practice, however, special educators typically function as the consultant-retaining the implication that their discrete expertise qualifies them best to fulfill that role (see, for example, Friend, 1985; Idol et al., 1986; Idol-Maestas \& Ritter, 1985). This underlying belief-that special educators are in the best position to help general educators solve classroom problems - inhibits the relationship between general and special educators and contributes to the following problems of practice.

The first problem with consultation is that a lack of congruence may exist between suggestions for classroom interventions made by consultants and general educators' understanding of those suggestions (Abidin, 1975; Gans, 1985). The training and experience of special education teachers generally is geared to individualized instructional settings, which are very different from the demands and pressures of the typical general education classroom.

This problem is compounded when the special educator in an intervention capacity is asked to consult with teachers regarding students who typically would not qualify for special education services. Special educators have limited experiences with these students. In such situations the consultant is likely to have little familiarity with both the students and the environments for which they are being asked to consult and provide suggestions regarding alternative approaches. It is in the context of this problem that we may hear classroom teachers reporting that consultants often make unrealistic suggestions.

Second, research from cognitive psychology would suggest that individuals may have difficulty attempting new strategies with which they have little prior experience. Vygotsky's "zone of proximal development" (see, for example, Wertsch, 1984) is a concept describing the relationship between independent problem-solving and one's existing level of development. With collegial guidance, one can reach new levels of development proximal to the existing onesbut one would not likely leap to an entirely new mode of functioning. Similarly, Rosenfield (1985) cites the notion of teachers" "working knowledge," reminding us that new and diverse information and skills are not assimilated easily. She states: "Teachers favor sources of knowledge and expertise that tend to be close by and within the same guild" (p. 156).

For special education consultants, the behavioral model is likely to be the preferred approach. Although other methodologies in general education have been developed as a means of accommodating diverse learners (e.g., Wang, 1987; Wang, Reynolds, \& Walberg, 1986), behavioral techniques that are less likely to be in the repertoire of classroom teachers continue to be suggested as an alternative. As a result, the interventions that special education consultants are most likely to propose are those that general educators may be least likely to use easily or accept.

Third, although special educators are beginning to receive training at the preservice level in concepts and issues associated with consultation, this is not commonly the case with students prepared in general programs of teacher education. Differential training underscores the preparedness of special educators to engage in consultation and the absence of preparedness of general educators to do so. Thus, a system has been created to support the assumption that the special educator is the one person appropriately trained to be a consultant. Not only are the skills of behavioral intervention deemed as the specialist's area of expertise but so also are the skills of consultation and collaboration themselves.

A fourth issue that inhibits the collaborative nature of consultation involves the attitudes that general and special educators hold regarding each other's abilities. Because of differences in training, general educators may question the ability of special education consultants to make suggestions that are realistic for implementation in the general classroom (Spodek, 1982). On the other hand, serious concern has been raised regarding general educators' abilities to modify their classroom structures to accommodate the needs of studenits with handicapping conditions (Aloia \& Aloia, 1982; Furey \& Strauch, 1983; Leyser \& Abrams, 1984; Johnson \& Johnson, 1980; Ringlaben \& Price, 1981).

Although general educators question the ability of special educators to make useful suggestions and may have greater faith in their own abilities to teach mildly handicapped students, special educators conversely question the abilities of general educators to identify and implement appropriate accommodations and have greater confidence in their own abilities to address the needs of handicapped students (Furey \& Strauch, 1983). This dissonance is a serious problem when consultation models of service delivery are initiated.

Finally, we must recognize that traditionally the provision of services to children with handicapping conditions simply 
has not been a shared partnership with general educators. General educators often have been ignored in the referred-toidentification process originally legislated in Public Law 94-142 and have played a secondary role in developing instructional plans for students with handicapping conditions, even situations in which the student's primary placement is the general education classroom. As the structure is now configured, the value of input from general educators is limited presumably because of their lack of knowledge and expertise with students who deviate from the norm. These attitudes on the part of special educators no doubt contribute to the tension that exists between special and general educators.

Before progress can be made toward developing an educational system that more equitably and efficiently addresses the needs of all students, we must recognize that both special and general education have contributed to less than ideal mutual relationships. In the special education literature, much has been written about general education's contribution to these problems. Now it is time to give careful and equal consideration to special education's contribution and to overcome the tendency toward a singularly hierarchical interpretation of consultation in which general educators are perceived to have less expertise and knowledge. If we continue to communicate this message in the practice of consultation, its success as an effective alternative to alleviate burdens now placed on the educational system will continue to be limited.

\section{CONSULTATION AS COLLABORATION: ALTERNATIVE CONSIDERATIONS}

To overcome these limitations so that consultation occurs in schools as a truly collaborative undertaking, its practice has to be reconceptualized along the following four dimensions:

1. Consultation should be a reciprocal, mutual activity among all professionals in a school.

2. Consultation should facilitate independent problemsolving skills on the part of general educators.

3. Consultation should be a routine part of interprofessional interaction and daily functioning.

4. The language used to discuss consultation should reflect its centrality in the school as a whole and not only its relationship to special education.

\section{Consultation as a Mutual and Reciprocal Schoolwide Activity}

To correct the assumption that only specialists are considered to be sources of consultation, consultation should be practiced as a mutual, reciprocal form of interaction. Certainly the deliberate expertise of those trained in special education is needed at times to resolve challenging learning and behavior problems. Likewise, however, general educators often possess crucial knowledge in specific subject areas, grouping for instruction, and knowledge of student performance within a group context-knowledge that may have particular import when students are making the transition from more segregated to more integrated settings. In current interpretations of consultation, the general educator is the recipient of expert advice from either a special education teacher or a school psychologist; rarely are general educators considered to possess expertise useful to special educators or school psychologists.

With consultation practiced as a reciprocal and mutual form of interaction, all professionals in a building would have the potential to be considered consultants in their areas of expertise. Consultation as a process would not belong solely to those who are not directly involved in general classroom education. In fact, the idea of the career or lead teacher, as conceptualized by the Holmes Group (1986) and the Carnegie Forum (1986) reform proposals, respectively, is consistent with the development of various kinds of expertise among the teaching staff in a particular school.

\section{Consultation as a Facilitative Process}

Consultation should facilitate independent problem-solving for teaching professionals as well as be a source of direct information. Teachers are used to approaching their colleagues for advice, and they typically receive a set of ideas tried previously by those colleagues, regardless of whether the advice is coming from a peer in general education or from a specialist. When this type of advice-giving comes from other classroom teachers, it is highly informal and impromptu, occurring often in the hallways or during teachers' brief lunch breaks. It most often is unsystematic, based on the assumption that others' experience is adequate as a central source of solutions to problems in school. In the specific case of special education consultation, general educators receive more formal advice regarding how to identify the problem, what kinds of interventions might be best to try, and how to keep track of those interventions.

The suggestions and prescriptions teachers and consultants offer to their colleagues during these interactions are 
well meaning, made in a spirit of helpfulness and sharing. In the short-term, they may be a source of useful ideas. But the long-term outcome of this kind of prescriptive, external advice-giving as the major mode of assistance is likely to work against teachers' gaining independence in solving classroom problems. Efficiency in the short-term, represented by existing conceptions of consultation, does not logically result in providing teachers with the means for increasing their own skills to better serve their students.

It is as if consultation is at cross-purposes with its intent. Although the overriding purpose is to create greater self-sufficiency on the part of general educators, consultation attempts to achieve this end by creating a dependent relationship between general and special education teachers. This is not to say that special education expertise is never needed; rather, it should be reserved for cases in which the issue or problem under consideration is clearly outside the general educator's expertise.

To reach this goal of long-term independence, the concept of consultation can be redefined to include not only prescriptive, advice-giving interaction, but interaction that facilitates independent problem-solving as well. We choose to call this form of consultation "facilitative consultation" as a way of defining its unique purpose: facilitating teachers' abilities to acquire specific problem-solving strategies themselves. In the facilitative mode, the consultant's job is to assist small groups or pairs of teachers in developing the necessary skills to reach their own solutions to classroom problems. The facilitative consultant displays trust in teachers' capabilities to own their own problems while also respecting their existing levels of expertise as problem solvers.

Consistent with the notion of the zone of proximal development, facilitative consultation requires great restraint, on the part of the consultant, from "giving" advice or solutions. Rather, teachers learn to guide each other to progressively more complex levels of problem-solving. This approach to consultation also entails a letting go of control that may not be easy, given the historical role of special educators in the schools.

One facilitative strategy the authors have been investigating with success is a highly structured dialogue known as peer collaboration (Pugach \& Johnson, 1988a, 1988b). In this process, pairs of general educators learn to use a series of specific strategies as a problem-solving technique based on the development of metacognitive thinking. The purpose is to encourage professionals encountering a problem to develop independent problem-solving skills under the guidance of a peer. In contrast to advice-giving, peer collaboration guides partners as they help peers develop their own solutions to problems through strategies such as clarification, self-questioning, and predicting outcomes of various solutions.

Facilitative consultants can learn to provide training to pairs of general education teachers in processes such as peer collaboration, and monitor their acquisition until teachers feel comfortable and skilled using them independently. With the capability to utilize a facilitative set of skills as the primary mode of consultation, accompanied by a set of prescriptive skills as needed, consultants can begin to differentiate, with greater confidence, problems requiring their specific knowledge and those for which solutions can be reached among general educators themselves.

\section{Consultation as a Routine Professional Role}

Finding time for consultation is a major challenge. Given the need for consultation to take place often and between all professionals in schools, work conditions must support its occurrence on a regular basis. Currently professionals have little, if any, time in which to confer and consult. Planning time is not the norm, nor is using existing meeting times for group meetings focusing on problem resolution. In attempts to implement existing models of special education consultation, identifying and reserving time for it to take place has been one of the major obstacles identified by advocates (Idol-Maestas \& Ritter, 1985). There is no reason to think this will not continue to be a problem with truly collaborative forms of consultation as well.

For the value of consultation to be operationalized in schools, time for interaction has to be built into the school day. Should more widespread, facilitative norms of consultation be enacted, however, that time cannot be associated only with special education and its attendant regulations. Reorganizing schooling to provide time for teachers to interact professionally is likewise one of the hallmarks of reform proposals (Carnegie Forum, 1986; Holmes Group, 1986).

Major reorganization and differentiation of staffing to provide teachers with clerical and routine assistance for noninstructional tasks is essential in targeting time for professional interaction. In the interim, some more immediate ways of providing time may be workable. For instance, schoolwide schedules could be organized so the time of various content-area specialists (music, art, physical education, etc.) regularly would allow a subgroup of teachers (for example, grade-level teachers) to meet specifically for purposes of problem-solving. Special and general educators might team-teach to provide more options for various con- 
figurations of professionals to interact. Regularly scheduled planning time then could be devoted to facilitative consultation.

Also, principals could reserve faculty meetings for consultation purposes on a regular basis (for example, every third faculty meeting) and deal with procedural issues in less time-consuming ways; small groups of teachers could be formed early in the year as teams to work at these meetings. These are only a few examples of ways to begin rethinking the problem of time needed for consultation that would reorient consultation as a regular schoolwide activity among all professionals.

\section{The Language of Consultation}

The final issue has to do with the language we use to describe and locate consultation in the operation of schooling. Because the term "consultation" typically has been applied to services deriving from special education and school psychology, it retains its association with carefully delimited expertise and with a professional hierarchy in schools. In more meetings than we care to remember involving the relationship between special and general education, we hear general educators describe themselves as "just regular teachers," and learn of the failures of consultation because of its singularly one-way meaning as expert-to-novice delivery of information.

Issues of language are paramount because language is the medium through which the norms of consultation are introduced and maintained. Whether consultation is presented and implemented as a function solely of special education or of education in general is dependent largely upon both explicit and assumed meanings ascribed to the term and its practice. Professionals within a particular specialization usually have difficulty recognizing the impact on their peers of the specialized terminology they use routinely. Special care and a measure of objectivity both are necessary in choosing terminology to describe new approaches and practices such as consultation.

A troublesome, timely example of a language problem is the unfortunate use of the term "regular education initiative" to denote special education's concern with the relationship between itself and general education. The way in which the REI movement is being framed continues to set up special and general education as two parallel systems rather than special education being a subspecialty within general education. Because of this, the very problems the REI is attempting to overcome are intensified rather than reduced.
Further, notwithstanding the fact that the relationship between special and general education requires redefinition, special educators should not be surprised that more "regular" educators are not interested in or knowledgeable about REI. After all, even though reforms in special education are part of the REI, it is essentially a term that special educators developed to describe, in large part, their view of what should change in "regular" education. Even so, all too frequently special educators wonder why more general educators are not involved in discussions of REI. Realistically, how would we as special educators react if we were to learn of a movement developed in general education that had as a major component the need to reform special education?

It is critical that we understand the inhibiting or facilitating power of connotations associated with new reforms and movements for which we advocate, and the responsibility for the effect of the terms used should lie with the professionals promoting their use. Consider how quickly the term REI has become integrated into the vocabulary of special education. It is now part of our jargon with little consideration for its meaning and the assumptions it embraces.

In the case of consultation, the term typically is introduced as a new form of special education service delivery or as a new role for school psychologists. Although teachers are likely to welcome more efficient and informal modes of assistance, they may at the same time understand that consultation is necessary because of their own shortcomings as teachers. As a function of specialized services, consultation may seem proper only as a professional activity within special education: Consultation is what you do when you have a student who is going to require special education. In some districts consultation is being proposed as a requirement, a step that must be taken before the referral process occurs. It may even be listed on a referral form as a prior service required before a referral can be processed.

Clearly, consultation prior to referral is not in itself problematic; in fact, it should occur regularly. The difficulty comes in isolating consultation as a step in the special education continuum of services rather than as a building-wide norm for problem-solving. It is not even essential to use the term "consultant" or "consulting teacher," thereby reserving this practice for specialists. Consultation can be presented as one of the goals of professional interaction that can be expected to take place in a particular building.

It is just as imperative that consultation not be defined as, or limited to, solving problems associated with student deficits. Teachers face many problems that are unrelated to 
student deficits. For example, accommodating the needs of students with outstanding ability can be a highly perplexing problem. Developing alternative instructional approaches in general, or identifying schoolwide needs for curriculum change, are issues that might require a consultative approach. Consultation has the potential to serve as a tool that will make the classroom and the school itself a more enriching and growth-producing environment for all students-but only if it is cut loose from its singular association with special services.

We also must examine the use of terms such as prereferral and preplacement. "Pre" implies that this is something we must do while we wait for special education services. Or, more troublesome, it suggests that we engage in developing alternative strategies in the classroom only when we already are considering special education as a possibility. This orientation prevents growth by creating a system that reacts to problems rather than initiates innovations.

One might argue that good teacher consultants would not let such things happen, and that districts implementing consultation as a collaborative concept would plan carefully to avoid such difficulties. The danger, however, lies in the rapid spread of practices associated with prereferral by districts and states as they attempt to institutionalize less formal, more efficient distribution of special education services. Even the best intentioned mandated practice can all too quickly take on the form of rule-driven behavior at the implementation stage. In the case of special education services, the regulatory nature of its practices is perhaps its most salient feature (Lilly, 1988), and the way to which the field is heavily accustomed. Relying on the language of expertise to introduce consultation is likely to result in its lukewarm reception. What to special educators may appear to be a flexible mode of service delivery might be interpreted among general educators as greater institutionalization of its practice. Although issues of language are more easily workable than the fundamental end of having teachers work collaboratively in schools; they reflect the philosophical environment in which consultation is introduced and thus deserve focused consideration at the planning stages.

\section{CONCLUSIONS}

In closing, consultation is an important activity for education professionals, and its practice should be encouraged. If it is implemented well, consultation has the potential to enhance the educational environment significantly and is supported in the intent of the education reform movement. As it is now practiced, however, consultation is predicated on the faulty presupposition that special educators and school psychologists are singularly able to provide expertise in the consulting role. This one-way notion greatly impedes the success of consultation and prevents it from being a collaborative form of interaction.

Potential problems associated with the implementation of schoolwide collaboration through consultation are not insurmountable. But preventing implementation problems will take great changes on the part of specialists regarding their roles and relationships. The following guidelines should be considered when implementing new consultation programs:

- Planning for consultation has to be a joint process, including both special and general education personnel.

- The skills of all professionals in a building have to be identified to clarify sources of expertise in various areas, of which special education is but one.

- The language associated with the introduction of consultation has to reflect its role as a schoolwide professional activity, not a special education-related activity alone.

- Consultation should not be identified simply as a requirement to be completed before special education referrals are made.

- Consultants need the skills to provide facilitative assistance as well as prescriptive advice.

The term "consultation" has at least two meanings: One is to give professional advice, and the other is to deliberate together. The purpose of the analysis offered here is to encourage districts and district personnel to err on the side of the second definition when implementing programs of consultation. Only in the context of joint deliberation does consultation have the potential to change the way adults interact in schools. In our opinion, consultation will never be succssful as long as it represents special education's answers to the problems of general education. We must develop a partnership in which problems and solutions are shared equally. With joint deliberation as the guiding principle toward development of such a partnership, the goal of collaboration-which places special education as a lateral, not a vertical, source of assistance-is surely within our grasp. As a beginning, please share this issue with your colleagues in general education. 


\section{REFERENCES}

Abidin, R.R. (1975). Negative effect of behavioral consultations: "I know I ought to, but it hurts too much." Journal of School Psychology, 13, 51-57.

Aloia, G.F., \& Aloia, S.D. (1982). Variations in expectations of the mainstreamed handicapped child by regular and special education teachers. Journal of Special Educators, 19(1), 13-19.

Carnegie Forum on Education and the Economy. (1986, May). A nation prepared: Teachers for the 21st century. New York: Carnegie Corp.

Evans, S. (1980). The consultant role of the resource teacher. Exceptional Children, 46, 402-404.

Fox, W.L., Egner, A.N., Paolucci, R.E., Perelman, P.F., McKenzie, H.S., \& Garvin, J.S. (1973). An introduction to a regular classroom approach to special education. In E.L. Deno (Ed.), Instructional alternatives for exceptional children. Reston, VA: Council for Exceptional Children.

Friend, M. (1985). Training special educators to be consultants. Teacher Education \& Special Education, 8(3), 115-120.

Fuchs, D., \& Fuchs, L.S. (In press). Mainstream assistance teams to accommodate difficult-to-teach students in general education. In J.L. Graden, J.E. Zins, \& M.J. Curtis (Eds.), Alternative educational delivery systems: Enhancing instructional options for all students. Washington, DC: National Association of School Psychologists.

Furey, E.M., \& Strauch, J.D. (1983). The perceptions of teacher skills and knowledge by regular and special educators of mildly handicapped students. Teacher Education \& Special Education, 6(1), 46-50.

Gans, K.D. (1985). Regular and special educators. Teacher Education \& Special Education, 8(4), 188-189.

Graden, J.L., Casey, A., \& Christenson, S.L. (1985). Implementing a prereferral intervention system: Part I. The model. Exceptional Children, $51,377-384$.

Holmes Group. (1986). Tomorrow's teachers: A report of the Holmes Group. East Lansing, MI: Author.

Idol, L., Paolucci-Whitcomb, P., \& Nevin, A. (1986). Collaborative consultation. Rockville: MD: Aspen.

Idol-Maestas, L. (1986). Setting the stage for successful school consultation. In C.L. Warger \& L.E. Aldinger (Eds.), Preparing special educators for teacher consultation. Toledo, $\mathrm{OH}$ : University of Toledo.

Idol-Maestas, L., \& Ritter, S. (1985). A follow-up study of resource/consulting teachers. Teacher Education \& Special Education, 8(3), 121131.
Johnson, D.W., \& Johnson, R.T. (1980). Integrating handicapped students into the mainstream. Exceptional Children, 47, 90-98.

Johnson, L.J., Pugach, M., \& Hammitte, D. (In press). Barriers to special education consultation. Remedial \& Speciai Education.

Leyser, Y. \& Abrams, P.D. (1984). Changing attitudes of classroom teachers toward mainstreaming through in-service training. Clearing House, 57, 250-255.

Lilly, M.S. (1988, April). The regular education initiative: A force for change in general and special education. Paper presented at the CEC Conference on Mental Retardation, Honolulu, HI.

Ponti, C.R., Zins, J.E., \& Graden, J.L. (1988). Implementing a consultation-based service delivery system to decrease referrals for special education: A case study of organizational considerations. School Psychology Review, 17, 89-100.

Pugach, M., \& Johnson, L.J. (1988a). Peer collaboration: Helping teachers help themselves. Teaching Exceptional Children, 20 (3), 75-77.

Pugach, M., \& Johnson, L.J. (1988b). Peer collaboration: Enhancing teacher problem-solving capabilities for students at risk. Paper presented at the Annual Meeting, American Educational Research Association, New Orleans. (ERIC Document No. SP 030114)

Ringlaben, R.P., \& Price, J. (1981). Regular classroom teachers' perceptions of mainstreaming effects. Exceptional Children, 47, 302-304.

Rosenfield, S. (1985). Teacher acceptance of behavioral principles. Teacher Education \& Special Education, 8, 153-158.

Sargeant, L.R. (1981). Resource teacher time utilization: An observational study. Exceptional Children, 47, 420-425.

Shapiro, E.S. (1987). Behavioral assessment in school psychology. Hillsdale, NJ: Lawrence Erlbaum.

Spodek, B. (1982). What special educators need to know about regular classrooms. Educational Forum, 46, 295-307.

Tharp, R.G., \& Wetzel, R.J. (1969). Behavior modification in the natural environment. New York: Academic Press.

Wang, M.C. (1987). Toward achieving educational excellence for all students: Program design and student outcomes. Remedial \& Special Education, 8(3), 25-34.

Wang, M.C., Reynolds, M.C., \& Walberg, H.J. (1986). Rethinking special education. Educational Leadership, 44, 26-31.

Wertsch, J.V. (1984). The zone of proximal development: Some conceptual issues. In B. Rogoff \& J. Wertsch (Eds.), Children's learning in the ZPD (pp. 7-18). San Francisco, CA: Jossey-Bass.

\section{ALERT}

\section{New Book}

\section{Community Colleges and Students with Disabilities A Directory of Services and Programs} American Association of Community and Junior Colleges and American Council on Education

Educating students with disabilities is the norm in U.S. 2 -year colleges today. Over 700 of the nation's community, junior, and technical colleges are included in this directory.

Designed especially for special service providers, coun- selors, campus administrators, and others who work with disability issues and students, the directory allows users to identify programs and contact services at 2-year colleges. The state-by-state section gives a listing of services and programs by institution in all areas of campus life (academic, physical and technological, and student support), types of disabilities served, and examples of agreements or contracts with community agencies. The index gives an alphabetical listing of colleges along with the types of disability groups served.

This handy resource is available from AACJC Publication Sales, 80 S. Early Street, Alexandria, VA 22304. Or contact AACJC by phone at 703/823-6966. 


\title{
Teacher Management and Helping Style: How Can We Develop Student Self-Control?
}

\author{
Charles A. Chrystal
}

Teacher management styles relevant to the education of students with learning and behavior problems have been described in the research and professional literature frequently. Differences in management style have implications for developing students' internal controls and behavioral responses. The teacher's multifaceted role necessitates a multidimensional understanding of management principles and practices (Schmid, Algozzine, Maher, \& Wells, 1984). I hope to provide such an overarching perspective on teacher management or helping style bearing upon intervention.

Many authors have differentiated between "traditional" and more egalitarian approaches to discipline. The traditionalist takes complete responsibility for classroom management, telling students what to do and when and how to do it. Academic tasks as well as behävioral requirements are often codified, and penalties are stipulated for noncompliant behavior. In contrast, the egalitarian teacher has a freeing effect, giving students reasonable leeway to make decisions within a democratic atmosphere.

Early researchers (Lippitt \& White, 1958; White \& Lippitt, 1960) described "autocratic" and "democratic" teachers, demonstrating the significance of group participation in decision making for student self-direction. "Laissezfaire" teachers, representing a variant "permissive" orientation, were found to be ineffective for inculcating student responsibility. Theory $\mathrm{X}$ and theory $\mathrm{Y}$ managers (the former representing directive management, the latter a more participative approach) were described at about the same time by McGregor (1960), an organizational psychologist frequently cited in the educational literature.

The distinction between "tough" teachers and their "fair" counterparts has persisted despite attempts to explain the complexity of classroom leadership style (Moos, 1979; Soar \& Soar, 1979). This probably stems from the fact that bifurcation aids research design and makes sound conceptual sense. "Authoritarian" and "humanistic" teaching styles recently have been described (Harris, Halpin, \& Halpin, 1985) using a conceptual scheme that owes much to Lippitt and White (cf., Willower, Eidell, \& Hoy, 1973). The authoritarian teacher is coercive, impersonal, and punitive, functioning within a "teacher-centered" environment. Humanis-

Charles Chrystal is affiliated with the Department of Exceptional Education, State University College at Buffalo.

(C) Love Publishing Company, 1988. tic teachers are "student-centered"-flexible, personable, and relatively lenient. These teachers have been found to enhance self-confidence and responsibility among students (Harris, Halpin, \& Halpin, 1985), as well as favorable attitudes toward instruction and group skills (Schmuck \& Schmuck, 1983).

Recently, Brickman et al. (1982) advanced a model of "helping and coping" based on attribution theory. Their model, which derives from contemporary cognitivepsychological principles, provides an attractive alternative to the simplistic division of teachers into two camps. The four helping styles described are relevant not just to classroom management but to all of the human service professions as well. Brickman's moral, compensatory, medical, and enlightenment helping styles provide new perspectives on the helping process and its outcomes. Teachers of students with learning, social, and emotional impairments may especially benefit from understanding Brickman's model (Morse, 1985).

My goals are twofold:

1. To describe the helping styles Brickman and his colleagues have proposed, together with classroom management methods and techniques that are related to those predispositions.

2. To examine student, teacher, interpersonal, and institutional factors that may interfere with the teacher's attempts to develop students' internal controls.

\section{FOUR APPROACHES TO HELPING}

The helping styles Brickman et al. (1982) define are determined by two interacting factors: (a) the teacher's attribution of responsibility to students for the learning and behavioral problems they present (i.e., the degree of student blame perceived); and (b) the teacher's attribution of responsibility to students for finding solutions to their problems. The interaction of these factors provides four approaches to helping within the school and classroom: moral, compensatory, medical, and enlightenment.

\section{Moral Style}

The first helping style is the moral style. This orientation dictates that the student with the learning or behavioral problem is personally responsible for his or her predicament, as 
a result of either complacency or choice. The student also is viewed as responsible for finding a reasonable solution to his or her predicament. The teacher remains relatively detached, encouraging the student to succeed by virtue of initiative and hard work but providing little or no guidance in the process. Success-it if occurs-builds student self-esteem. Failure results in diminished self-confidence and, perhaps, resignation. "In the moral model," Morse (1985) states, "the world is a just place and you get what you deserve" (p. 128).

This unforgiving helping style rarely is employed by special education teachers, although some who went through the "school of hard knocks" believe that the moral approach is best for problem students. The moral approach requires the teacher's determination of correct behavior and student self-discipline in keeping with that standard. Appealing to values (cf., Redl \& Wineman, 1959) fits within the paradigm, as does reality therapy (Glasser, 1975), wilderness camping (Byers, 1979), and similar interventions emphasizing individual strength in the face of adversity.

\section{Compensatory Style}

The teacher who employs a compensatory approach typically does not perceive the student as responsible for his or her problem but does view the student as ultimately responsible for finding a solution to the predicament. The teacher's role is to be supportive and facilitative; the goal is to locate and allocate to the student appropriate resources dealing with learning and behavioral concerns. The teacher also makes himself or herself available as a material resource. Student mastery of problems promotes feelings of enhanced self-efficacy (Bandura, 1982). Failure may lead to feelings of alienation, the world being seen as an unjust place where some few persons are inflicted with problems through no fault of their own.

A great number of compensatory interventions are available to special educators. These include values clarification (Simon, Howe, \& Kirschenbaum, 1972), nondirective individual and group counseling, crisis intervention, and related techniques such as the Life Space Interview (Morse, 1980; Redl, 1959). Such interventions permit students to explore personal problems without stigma or blame. Cognitive behavior modification (Meichenbaum, 1977) and self-control strategies (Kendall, 1984) also foster student competence with provision of teacher support. Learning strategies (Alley \& Deshler, 1979) attempt to develop student independence in important academic areas, so these also may be considered compensatory. Group meetings such as those proposed by
Bates, Johnson, and Blaker (1982) and Ohlsen (1988), as well as more structured approaches to problem solving (Camp, Blom, Herbert, \& VanDoornik, 1977), also fit within the paradigm.

Several prominent educators have proposed curricular sequences or models that-if not expressly compensatoryhave the goal of developing students' internal controls. The self-control curriculum (Fagen, Long, \& Stevens, 1975) suggests games, role-playing activities, and discussions as avenues for building self-esteem and behavioral control among students. Cognitive as well as affective channels of intervention are employed.

Goldstein and his colleagues (Goldstein, 1981; Goldstein, Sprafkin, Gershaw, \& Klein, 1980) take a social learning approach: a sequence of goals for social development, together with modeling, role playing, feedback, and generalization techniques helpful in promoting prosocial behaviors. Hewett and Taylor (1980) promote a model of educational development, which facilitates student autonomy through the use of behavioral principles and techniques. And Rezmierski (1984) describes a cognitive-developmental model-complete with suggested interventions-which aids students in the area of impulse control. Although models and techniques vary, the message contained within each curriculum or sequence is identical: External sanctions for problem behavior must be replaced by internal mediation and student controls.

The moral and compensatory styles are similar to studentcentered orientations to classroom management, described earlier, as they ultimately give responsibility to students for solving their personal and behavioral problems. The compensatory style has most in common with the humanistic orientation (Willower et al., 1973), however, as it implies ongoing teacher support, Brickman and colleagues favor the compensatory style, because it fosters personal growth and development through relationship. Sabatino (1987) refers to this approach to helping as "preventative discipline": "The teacher's realization that discipline begins with a positive attitude that nurtures students' learning of personal, social, and academic skills" (p. 8). Generally speaking, then, the compensatory approach to helping best promotes students' self-control.

The medical and enlightenment styles of classroom management, discussed next, require the teacher's doing something to or for the student. Thus, they do not contribute much to the development of personal responsibility and selfcontrol. 


\section{Medical Style}

The medical approach is predicated upon the assumption that the student is responsible neither for his or her problem nor for finding a solution to it. The problem is viewed as the result of psychological, environmental, or biological forces outside of the student's control, and so requires expert treatment. In special education, the medical approach finds representation in token economies (Lahey \& Drabman, 1981) and other behavior modification techniques imposed upon students. Counseling approaches wherein the student is the passive recipient of help (e.g., psychoanalysis) are also representative. Biophysical interventions including drug therapy, nutritional and dietary regimens, physical manipulation, and so on further exemplify the medical approach to classroom management.

\section{Enlightenment Style}

The fourth helping style described by Brickman et al. is the enlightenment style. The student is viewed as responsible for his or her problem, and as unable or unwilling to come to grips with it. Corrective discipline frequently results: "what teachers do to get the horse back in the barn after the gate has been left open, or after the horse has kicked its way out" (Charles, 1981, p. 221). The enlightenment style is essentially reactive: The teacher may invoke logical consequences or punishment. Coercive adult behavior may exacerbate what are already dysfunctional student responses (Kazdin, 1988), and little or nothing is done to develop students' internal controls. Teacher vigilance is necessary to defend against further student misbehavior. The enlightenment style is most similar to the traditional, autocratic, authoritarian, and teacher-centered orientations to classroom management described previously.

\section{OBSTACLES TO EFFECTIVE MANAGEMENT}

Development of students' internal controls, it has been suggested, is fostered by supportive teacher behavior. The compensatory approach to helping, then, is the recommended one that teachers should strive to implement. Yet certain obstacles hinder application of that approach. In fact, the obstacles to helping from any perspective are many. These include student factors, teacher attitudes, interpersonal considerations, and institutional responses to student behavior.

\section{Student Factors}

To say that teaching students with learning and behavioral disorders is challenging is an understatement. Not only do these students present deficits in educational performance (Federal Register, 1977), but myriad learning disabilities, social and emotional handicaps as well. Overlapping student problems is the rule, not the exception (Gallico, Burns, \& Grob, 1988). Not only are instructional issues of concern, but complex problems of individual and classroom management also are involved. Some recent findings (Rezmierski \& Schiffler, 1983) indicate that approximately two thirds of students referred for help as "under stress" are either negative (disruptive, critical, blaming) or socially overinvolved with peers.

The control that students such as these exert over their behavior seems tenuous, at best. How can they be expected to deal effectively with their own problems, even with teacher support? In fact, working in a compensatory manner with some students may not be possible. Some with deficient value systems may require close supervision and a directive approach (Morse, 1985); others may be too young or too immature to take responsibility for their behavior.

The greater problem involves the nature of the teacher's role. Many teachers of learning and behaviorally disordered students seem overwhelmed by their professional responsibilities; a startling 50\% leave the field within 3 years (Lawrenson \& McKinnon, 1982). Also, many teachers wanting to assume disciplinary control possibly come down too hard on their students, unwittingly fueling behavior among students (Sabatino, 1987) and contributing to their own occupational discomfort. In keeping with this perspective, authoritarian or enlightened teachers report the highest level of stress (Harris, Halpin, \& Halpin, 1985).

This is not always the case, of course, but escalation of teacher-student conflict may at times be dealt with most productively by giving students behavioral latitude while indicating their responsibility for self-control. A structured classroom environment facilitating teacher access to students, sound organization and time management, interesting and educationally relevant assignments, intelligent grouping of students, and positive teacher-student interaction may permit the teacher to assume an indirect but supportive stance toward student self-management (Stainback, Stainback, \& Froyen, 1987). This perspective recognizes the importance of ecological variables for developing internal controls among students.

\section{Teacher Attitudes}

Teachers may be quick to impose solutions on students with learning and behavior problems (Chrystal, 1987). Research involving 160 special educators has demonstrated 
that the average teacher's expressed helping style is one that takes responsibility for solutions away from students. The combined medical-enlightenment orientation that the average teacher favors also leaves latitude for ascribing blame. It seems that a student viewed as a responsible for his or her behavior would receive some corrective form of discipline, and that a student viewed as unable to control his or her behavior would receive some form of treatment.

In either case, the teacher takes action while the student is perceived as the passive recipient of intervention. Clearly, this combined medical-enlightenment stance places heavy demands on the teacher and adds little to the student's development of internal behavioral controls.

I believe and contend that many teachers of learning and behaviorally disordered students suffer from this "attitude problem," which promotes the use of reactive forms of discipline. This attitude in part reflects adherence to the utilitarian perspective that whatever follows student behavior is what really matters, in part because teachers believe that they cannot-or should not-work in a proactive manner with students.

Morse (1985) correctly noted that human beings are rather more complex than simple S-R paradigms suggest, and that even learning and behaviorally disordered students are proactive as well as reactive in nature. This viewpoint seems to be gaining favor among special educators, particularly those who espouse "cognitive" models of instruction (cf., Gearheart, DeRuiter, \& Sileo, 1986; Reid \& Hresko, 1981). The "intentional psychological instruction" described by Nichols (1986) suggests means for capitalizing upon students' proactive capabilities through counseling and other compensatory techniques.

\section{Interpersonal Considerations}

Teachers of learning and behaviorally disordered students typically favor one of the four helping styles described, despite the fact that some adaptability in working with students and their problems is characteristic (Morse, 1985). Teachers rarely do work in a vacuum. Cooperative attempts at intervention are often necessary if a student is to make academic or behavioral progress. Administrators, other teachers, and parents may be involved in planning or implementing interventions. The student is also an important part of the equation. These parties, like the classroom reacher, have their own perspectives on intervention.

When parties agree in their perceptions of a student's responsibility for problems and solutions, it follows, from Brickman's model, that an intervention could be selected collaboratively and implemented with relative ease. Depending upon the "goodness" of the intervention, scholastic or behavioral improvements should follow. But, because perspectives on student problems may vary, disagreements may arise regarding interventions. Thus, disagreements in approach must be understood and dealt with productively.

Three types of disagreements may render the planning and implementing of intervention problematic. These are with regard to the student's (a) responsibility for problems, (b) responsibility for solutions, and (c) responsibility for both problems and solutions. These disagreements may not be immediately obvious, because assumptions about management of student problems are rarely discussed. Disagreements in approach often go "underground," functioning on subconscious level. But these disagreements may exert a profound impact upon intervention effectiveness and may have a pernicious effect upon interpersonal interaction and communication.

\section{Responsibility for Problems}

Disagreements regarding student responsibility for problems may arise between those discussing the parameters of behavioral or instructional dilemmas. Those holding moral and enlightenment management styles may view students as responsible for their problems, whereas medically oriented and compensatory helpers typically view the student as a victim of circumstance.

Moral and enlightenment helpers may voice skepticism regarding the student's problem, questioning the seriousness of the matter and suggesting that the student brought the problem upon himself or herself. Medical and compensatory helpers may defend the student, noting the impact of biophysical and environmental factors upon performance and thereby proclaiming the student's innocence. The final disposition may rest with the most persistent or powerful spokesperson, but the end result may be impaired communication and weakened intervention.

\section{Responsibility for Solutions}

Enlightenment and medically oriented parties may disagree with moral and compensatory helpers regarding the student's involvement in solving the presenting problem. The question is: To what degree should the student be responsible for change? Those with enlightenment and medical management styles may begin devising and implementing interventions without allowing for student input, whereas moral and compensatory helpers will push for greater student 
involvement. Again, misunderstanding and poor communication may have an adverse impact upon service delivery.

\section{Responsibility for Problems and Solutions}

The possibility of interpersonal confrontation and conflict is perhaps most real when involved parties differ regarding student responsibility for problems and for solutions. Moral managers may clash with their medical peers, and enlightenment helpers may challenge their compensatory counterparts. These ideological battles may severely damage collegial relationships, impeding the ability of teachers and other professionals to work cooperatively with respect to student problems.

Moralistic helpers may cause their more commonplace, medically oriented counterparts much exasperation. Moral helpers are prone to perceive medical managers as overly engaged or enmeshed in the intervention or management plan, whereas medically minded helpers may view moralists as remote, aloof, passive, or uncaring. Attempts that medically oriented helpers make to involve moralists in the intervention process typically fail. Mutual suspicion is the rule.

The compensatory practitioner is most frequently accused by his or her enlightened counterpart of being "soft." Familiar to many is the enlightenment-oriented co-worker or parent who insists that "all these kids need is a little discipline"- the implicit message being that the teacher is not sufficiently tough with students. Most teachers are distressed by such accusations and may protest that students with learning and behavioral problems require understanding rather than punishment or discipline. The ensuing discussion may find both the enlightenment individual and the compensatory teacher defending a preferred perspective-the result being that little or nothing is accomplished by way of effective intervention.

\section{Institutional Responses to Student Behavior}

Schools are custodial institutions-organizations wherein neither the organizations nor their clients have a choice about client participation in the organization. As such, schools must function efficiently and in an orderly manner (Carlson, 1964; Willower \& Lawrence, 1979). Policies and procedures are created within schools to ensure their smooth operation. Many learning and behaviorally disordered students, of course, inadvertently test the capacity of schools and their policies and procedures to deal with student problems. Behavioral excesses frequently are involved as the student runs afoul of the school authority system.
To the extent that students create problems or dissonance within the school's jurisdiction, schools become reactive and exclusionary in an effort to maintain organizational stability. Rubinstein and Rezmierski (1983) note that, at mild levels of dissonance, a curative approach to student problems emphasizing professional expertise is most typical. At moderate levels of dissonance, schools vacillate between "motivations to heal and to punish" (p. 63). And when schools experience high dissonance, punitive responses can be expected. Most striking is that these organizational responses are in keeping with the medical-enlightenment style of helping, which characterizes the average teacher of students with learning and behavior problems (Chrystal, 1987). If, in fact, a direct relationship exists between institutional and teacher approaches to intervention, the deck clearly is stacked against compensatory modes of intervention and classroom management fostering student responsibility.

\section{CONCLUSION}

Imposing interventions upon students with learning and behavioral disorders may come all too easily, given institutional priorities, teacher attitudes, and the helpless rage many teachers feel when working with such pupils (Redl, 1969). Traditional, autocratic, or enlightenment techniques and curative medicalistic approaches have great appeal. But can special education afford the "rescue mission complex" (Morse, 1985), which punishes when it cannot heal?

I believe that we should direct greater effort toward developing self-control among students with learning and behavior difficulties. This may not be easy, but methods and materials exist that may make the job easier. The National Special Education and Mental Health Coalition (Forness, 1988) also promises to bring new perspectives, techniques, and enthusiasm to educational practice. Educators cannot, however, afford to wait for other helping professionals to give direction to the field. As Jersild (1955) pointed out many years ago, educational practice must rest upon knowledge of students, teacher self-awareness, self-directedness, and professional ethics. Can special educators finally rise to that challenge?

\section{REFERENCES}

Alley, G., \& Deshler, D. (1979). Teaching the learning disabled abolescent. Denver: Love.

Bandura, A. (1982). Self efficacy mechanism in human agency. American Psychologist, 37, 747-756.

Bates, M., Johnson, C.D., \& Blaker, K. E. (1982). Group leadership: A manual for group counseling leaders. Denver: Love. 
Brickman, P., Rabinowitz, V. C., Karuza, J., Coates, D., Cohn, E., \& Kidder, L. (1982). Models of helping and coping. American Psychologist, 37, 368-384.

Byers, E. (1979). Wilderness camping as therapy for emotionally disturbed children: A critical review. Exceptional Children, 45, 628-635.

Camp, B., Blom, G., Herbert, F., \& VanDoornik, W. (1977). Think aloud: A program for developing self-control in young aggressive boys. Journal of Abnormal Child Psychology, 5, 157-168.

Carlson, R. (1964). Environmental constraints and organizational consequences: The public school and its clients. In D. Griffiths (Ed.), Behavioral science and educational administration (pp. 262-276). Chicago: University of Chicago Press.

Charles, C. (1981). Building classroom discipline: From models to practice. New York: Longman.

Chrystal, C. A. (1987). Helping styles of special education teachers: Some preliminary findings. Perceptions, 24(3), 12.

Fagen, S., Long, N., \& Stevens, D. (1975). Teaching children self-control: Preventing emotional and learning problems in the elementary school. Columbus, $\mathrm{OH}$ : Merrill.

Forness, S. R. (1988). Planning for the needs of children with serious emotional disturbance: The National Special Education and Mental Health Coalition. Behavioral Disorders, 13, 127-133.

Gallico, R. P., Burns, T. J., \& Grob, C. S. (1988). Emotional and behavioral problems in children with learning disabilities. Boston: Little, Brown.

Gearheart, W. R., DeRuiter, J., \& Sileo, T. (1986). Teaching mildly and moderately handicapped students. Englewood Cliffs, NJ: Prentice-Hall.

Glasser, W. (1975). Reality therapy: A new approach to psychiatry. New York: Harper \& Row.

Goldstein, A. P. (1981). Psychological skill training. Elmsford, NY: Pergamon.

Goldstein, A. P., Sprafkin, R. P., Gershaw, N. J., \& Klein, P. (1980). Skillstreaming the adolescent: A structured learning approach to teaching the prosocial skills. Champaign, IL: Research Press.

Harris, K., Halpin, G., \& Halpin, G. (1985). Teacher characteristics and stress. Journal of Educational Research, 78, 346-350.

Hewett, F., \& Taylor, F. (1980). The emotionally disturbed child in the classroom: Orchestration of success (2nd ed.). Boston: Allyn \& Bacon.

Jersild, A. (1955). When teachers face themselves. New York: Teachers College Press.

Kazdin, A. E. (1988). Child psychotherapy: Developing and identifying effective treatments. New York: Pergamon.

Kendall, P. C. (1984). Annotation: Cognitive-behavioural self-control therapy for children. Journal of Child Psychology \& Psychiatry, 25, 173-179.

Lahey, B., \& Drabman, R. (1981). Behavior modification in the classroom. In W. Craighead. A. Kazdin, \& M. Mahoney, (Eds.), Behavior modification. Boston: Houghton-Mifflin.

Lawrenson, G., \& McKinnon, A. (1982). A survey of classroom teachers of the emotionally disturbed: Attrition and burnout factors. Behavioral Disorders, 8, 41-49.

Lippitt, R., \& White, R. W. (1958). An experimental study of leadership and group life. In E. Maccoby, T. Newcomb, \& E. Hartley (Eds.), Readings in social psychology (3d ed.). New York: Holt, Rinehart \& Winston.

McGregor, D. (1960). The human side of enterprise. New York: McGrawHill.

Meichenbaum, D. (1977). Cognitive-behavior modification: An integrative approach. New York: Plenum.
Moos, R. H. (1979). Evaluating educational environments. San Francisco: Jossey-Bass.

Morse, W. C. (1980). Worksheet on life span interviewing. In N. Long, W. Morse, \& R. Newman (Eds.), Conflict in the classroom (4th ed.). Belmont, CA: Wadsworth.

Morse, W. C. (1985). The education and treatment of socioemotionally impaired children and youth. Syracuse, NY: University Press.

Nichols, P. (1986). Down the up staircase: The teacher as therapist. Teaching: Behaviorally Disordered Youth, 2, 1-13.

Ohlsen, M. M. (1988). Encouraging personal growth in school groups. In J. Carlson \& J. Lewis (Eds.), Counseling the adolescent: Individual, family, and school interventions (pp. 239-258). Denver: Love.

Redl, F. (1959). The concept of life space interviewing. American Journal of Orthopsychiatry, 29, 1-18.

Redl, F. (1969). This is what kids stir up in us: Problems of emotional hygiene for the educational adult. Proceedings of the First Annual Convention of the Association of New York State Teachers of the Emotionally Disturbed, 1, 3-14.

Redl, F., \& Wineman, D. (1959). The aggressive child. New York: Free Press.

Reid, D. K., \& Hresko, W. P. (1981). A cognitive approach to learning disabilities. Englewood Cliffs, NJ: Prentice-Hall.

Rezmierski, V. (1984). Developmental interventions with behaviorally disordered youth. In J. Grosenick, S. Huntze, E. McGinnis, \& C. Smith (Eds.), Social/affective interventions with behavioral disorders. Des Moines: Iowa Dept. of Public Instruction.

Rezmierski, V., \& Schiffler, N. (1983). Prevalence and persistence of teacher-perceived emotional problems in school-aged youth. Available from V. Rezmierski, School of Education, University of Michigan, Ann Arbor, MI.

Rubinstein, M., \& Rezmierski, V. (1983). Understanding nonproductive system responses to emotionally disturbed and behaviorally disordered students. Behavioral Disorders, 9, 60-67.

Sabatino, D. A. (1987). Preventative discipline as a practice in special education. Teaching Exceptional Children, 19(4), 8-11.

Schmid, R., Algozzine, B., Maher, M., \& Wells, D. (1984). Teaching emotionally disturbed adolescents: A study of selected teacher and teaching characteristics. Behavioral Disorders, 9, 105-112.

Schmuck, R. A., \& Schmuck, P. A. (1983). Group processes in the classroom (4th ed.). Dubuque, IA: Wm. C. Brown.

Simon, S. B., Howe, L. B., \& Kirschenbaum, H. (1972). Values clarification: A handbook of practical strategies for teachers and students. New York: Hart.

Soar, R. S., \& Soar, R. M. (1979). Emotional climate and management. In P. L. Peterson \& H. J. Walberg (Eds.), Research on teaching: Concepts, findings, and implications (pp. 97-119). Berkeley, CA: McCutcheon.

Stainback, W., Stainback, S., \& Froyen, L. (1987). Structuring the classroom to prevent disruptive behaviors. Teaching Exceptional Children, 19(4), 12-16.

White, R. W., \& Lippitt, R. (1960). Autocracy and democracy. New York: Harper \& Bros.

Willower, D., Eidell, T., \& Hoy, W. (1973). The school and pupil control ideology (2nd ed.). University Park, PA: Penn State Studies.

Willower, D., \& Lawrence, J. (1979). Teachers' perceptions of student threat to teacher status and teacher pupil control ideology. Psychology in the Schools, 16, 586-590. 


\section{Excellent new texts}

\section{D.ceplanal Children and routhe An mintroduction}

\section{Third Edition}

Edited by Edward L. Meyen and Thomas M. Skrtic, University of Kansas

This is a totally new revision of a popular and widely adopted introductory text. It covers all exceptionalities and includes much new material. Implications of the regular education initiative are examined, and chapters on family dynamics and multicultural concerns have been added. This significant revision covers the important changes, issues, and contemporary practices in special education.

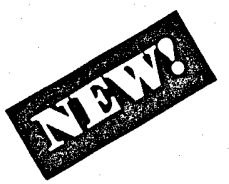

We are proud to present this exciting book that is on the cutting edge of the field - presenting both traditional, proven ideas and emerging perspectives. It will stimulate your thinking.

\section{teaching stuclents with Behavior Disorders

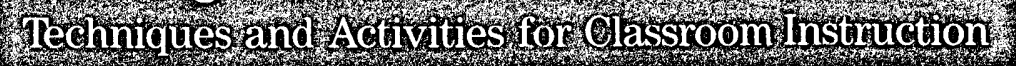

\section{Second Edition}

Patricia A. Gallagher, University of Kansas

This excellent new revision gives

current strategies and techniques that really work. It is chock-full of activities for classroom instruction that will make your class a joy for your students. Many examples, photos, illustrations, forms, and vignettes make this book lively, contemporary, and easily understood.

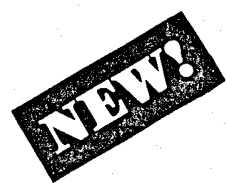

Teaching Students with Behavior Disorders has been updated and expanded to include the latest practical tools for working with troubled children.

\section{Griective instrictional Strateges or Drceptional Gildien}

Edited by Edward L. Meyen, University of Kansas

Glenn A. Vergason, Georgia State University

Richard J. Whelan, University of Kansas Medical Center

This new book of practical strategies for teaching children with special needs gives the latest effective methods. It will help teachers understand the "why, what, how, and

8828/paper/ISBN 0-89108-201-8 when" of strategies with this population.

Many of the essays are from Focus on Exceptional Children. The book is readable and without question up-to- date. The book covers assessment, instructional organization, and effective teaching strategies.

It is proven and contains the latest thinking.

\section{LOVE PUBLISHING COMPANY}

1777 South Bellaire Street, Denver, Colorado 80222 303-757-2579 


\section{Professional update}

\section{UPCOMING MEETINGS}

\section{December 8-10, 1988}

Association for Persons with

Severe Handicaps

Washington Hilton Hotel

Washington, DC

Contact: TASH

$$
\text { (206) 523-8446 }
$$

\section{December 11-13, 1988}

Council for Exceptional Children

Special Education Technology Conference

Reno, NV

\section{Contact: CEC}

$$
\text { (703) } 620-3660
$$

\section{February 15-18, 1989}

Association for Children and Adults with Learning Disabilities

Fontainebleau Hilton

Miami Beach, FL

Contact: ACLD

(412) 341-1515

\section{April 3-7, 1989}

Council for Exceptional Children

San Francisco, CA

Contact: CEC

$$
\text { (703) 620-3660 }
$$

\section{May 10-13, 1989}

International Conference

Innovations in Special Education

Kansas City, MO

Contact: J.M. Caccamo

(816) 833-3433

\section{May 17-20, 1989}

International Conference in Special Education Vancouver, British Columbia Canada 